\title{
Cores, gastronomia e cinema: um estudo sobre a representação da gastronomia no cinema
}

\section{Colors, gastronomy and cinema: a study on the representation of gastronomy on cinema}

\author{
Luanda Batista Demarchi dos Santos - Coordenadora do curso de Tecnologia em Gastronomia do Instituto \\ Federal de Minas Gerais (IFMG). Brasil. - luanda.batista@ifmg.edu.br
}

Lucas Rodrigues da Silva - Tecnólogo em Gastronomia. Instituto Federal de Minas Gerais (IFMG). Brasil. lughas@gmail.com

\author{
Palavras-chave: \\ Gastronomia. Cinema. \\ Filmes Gastronômicos. \\ Cores. Paleta \\ Cromática.
}

\section{Keywords:}

Gastronomy. Cinema.

Gastronomic films.

Colors. Chromatic

palette.
Informaçöes do artigo Recebido em: 25-06-18 Aprovado em: 30-11-18

\section{RESUMO}

O boom ocorrido na gastronomia no final da década de 90 aumentou o contato da população com o assunto. A produção no cinema sobre a matéria cresceu demasiadamente, alcançando o número de 58 películas gastronômicas entre os anos 2001 - 2010. O trabalho analisa a paleta cromática, assumindo que as cores possuem significados próprios, de seis filmes gastronômicos lançados entre 1991 - 2010. Para a realização da pesquisa, metodologias do audiovisual foram estudadas e decidiu-se a utilização das análises conotativa e diacrônica, sendo um levantamento de material histórico relativo ao uso de cores naquele produto, filmes neste caso, com finalidade de detectar, conhecer e compreender mudanças tecnológicas, culturais e da percepção das pessoas em relação às cores, além do emprego de softwares e observação comentada, filtrando apenas as cenas que retratam a cozinha, o cozinhar e a comensalidade. Foi possível observar como a cozinha e o cozinhar eram retratados de uma forma escura na década de 90 e coloridos nos anos de 2001 - 2010, já a comensalidade, em ambas as décadas, foi representada de maneira mais colorida. Como conclusão, fica evidente a evolução da representação da gastronomia no cinema através da paleta cromática, com filmes mais novos retratando a imagem da cozinha e do cozinhar positivamente.

\section{ABSTRACT}

The boom occurred in the gastronomy in the late 1990s increased the population's contact with the subject. Film production on the subject has grown overmuch, reaching the number of 58 gastronomic films between the years 2001 - 2010. The work analyzes the color palette, assuming that the colors have their own meanings, from six gastronomic films released between 1991 and 2010. In order to carry out the research, audiovisual methodologies were studied and it was decided to use the connotative and diachronic analyzes, being a survey of historical material related to the use of colors in that product, films in this case, with the purpose of detecting, knowing and understanding technological, cultural and people's perception of colors changes, as well as the use of software and commented observation, filtering only the scenes that portray the kitchen, cooking and commensality. It was possible to observe how the kitchen and cooking were portrayed in a dark form in the 90's and colorful in the years 2001 - 2010, meanwhile the commensality, in both decades, was represented in a more colorful way. As a conclusion, the evolution of the representation of gastronomy in the cinema through the chromatic palette is evident, with newer films portraying the image of the kitchen and of cooking positively.

Como citar este artigo

SANTOS, Luanda Batista Demarchi dos; SILVA, Lucas Rodrigues da. Cores, gastronomia e cinema: um estudo sobre a representação da gastronomia no cinema. Revista Brasileira de Gastronomia, Florianópolis, v. 2, n. 1, p. 26-47, jan./jul. 2019. Disponível em: http://rbg.sc.senac.br/index.php/gastronomia/article/view/11. Acesso em: dd $\mathrm{mm}$ aa. 


\section{INTRODUÇÃO}

A disciplina Gastronomia e o estudo da comensalidade envolvem não apenas o ato de comer, mas também o comportamento social e a interdisciplinaridade com outras áreas de conhecimento como a química, antropologia, física, medicina e etc. formando um campo muito vasto de pesquisa com alicerces que remontam a antiguidade. Brillat-Savarin (1995, p. 15) exprime "1. O Universo nada significa sem a vida, e tudo o que vive come. 2 . Os animais se repastam; o homem come; somente o homem de espírito sabe comer", sendo que o prazer da comida, transformação e experimentos relacionados a elaboração de um alimento devem ser considerados como uma forma de arte, percebida em diversos povos (BARRRETO, 1999; BRILLAT-SAVARIN, 1995).

A cor possui ampla capacidade expressiva e simbólica, transmite mensagens e significados (OLIVEIRA, 2016, p. 29). Este artigo busca analisar a competência das cores através da sétima arte, o cinema, com foco nos filmes gastronômicos, em específico nas cenas com representação da cozinha, do preparo de alimentos e a comensalidade.

Foi identificado um gênero de filmes crescente, classificados por Yasoshima (2012) como filmes gastronômicos. Assumindo que a cor possui aspectos psicológicos, este artigo busca analisar os sentimentos que essas cores despertam no espectador nas cenas relacionadas à gastronomia.

A pesquisa pretende analisar cenas cinematográficas e associar com as paletas de cores, procurando analisar se há um padrão de cores entre as cenas semelhantes de diferentes filmes, percebendo um padrão entre as cores e a evolução de sua apresentação, realizando uma comparação história entre filmes publicados em 1991 - 2000 e 2001 - 2010. O recorte de tempo foi pensado no período pré e pós boom gastronômico.

O boom da gastronomia ocorreu no final dos anos 90 e modificou o entendimento que a população tinha sobre gastronomia e, consequentemente, a sua forma de representação na mídia e na arte. Luderer $(2013$, p. 417) em sua tese de doutorado intitulada "O Papel dos ChefsCelebridades na Construção do Espetáculo da Alimentação: análise discursiva das revistas de gastronomia de luxo" afirma que com o boom em torno da gastronomia, os profissionais passaram a ter maior visibilidade e espaço para expor seus discursos, escrevem livros, participam de programas de televisão e há colunas em jornais e revistas utilizando a comida como modo de adquirir audiência.

No Brasil, é possível perceber o crescimento dos cursos superiores em gastronomia nessa época. Os primeiros surgiram em 1999 na Universidade do Sul de Santa Catarina (bacharelado em Turismo com habilitação em Gastronomia); Anhembi-Morumbi (Curso superior sequencial em 
Gastronomia) e na Universidade do Vale do Itajaí (graduação e sequencial em Gastronomia). Em 2016, segundo o Índice Geral de Cursos do Instituto Nacional de Estudos e Pesquisas Educacionais Anísio Teixeira (INEP), o Brasil contava com 106 cursos de gastronomia.

Assim como em Schwendler (2015) “As Cores e o Cinema: uma análise do filme Moonrise Kingdom (2012), de Wes Wanderson" foi necessária uma pesquisa que envolveu os principais assuntos do trabalho: cor e filmes gastronômicos. Sendo necessário dois métodos distintos: pesquisa bibliográfica e análise audiovisual.

Foram escolhidos 6 filmes no total, sendo três da década de 90 e três da primeira década do século XXI. Os filmes deveriam ser relevantes em alcance popular, portanto foi analisado:

- a bilheteria do filme, descartando os filmes inferiores a: 20.000.000,00 (vinte milhões de dólares). O valor de bilheteria de cada filme foi pesquisado no website Internet Movie Database $(\mathrm{IMDb})^{1}$;

- a nota do filme no website Internet Movie Database (IMDb), descartando os que não obtiveram pelo menos: 6,0 .

A escolha do IMDb se deu devido a sua popularidade, segundo Oliveira (2016) o site contém 60 milhões de filmes registrados e é o 57오 site mais acessado no mundo. Neste website os usuários podem dar notas de 1 a 10 aos filmes. Com a nota e a bilheteria pode-se filtrar aqueles que realmente tenham sido populares e assistidos. Houve também um recorte geográfico, excluindo-se filmes orientais por possíveis discrepâncias culturais.

Kellner (2000) afirma que o cinema surgiu como uma das primeiras formas culturais de produção em massa do século XX, e favoreceu o surgimento de um novo modo de cultura que mudou os padrões das atividades de lazer e teve um importante papel na vida social. Segundo Ricci (2003), o uso de filmes como fonte de pesquisa não pode ser tomado como ilustração e/ou complemento do texto escrito, pois ele possui uma linguagem própria. É preciso entendê-lo como uma representação da sociedade e não uma evidência do real. O filme é uma montagem, assim sendo, "não há filme neutro tanto em relação à sociedade onde foi produzido, como ao ser visto e outros lugares, divulgando valores e ideias" (RICCI, 2003, p. 42).

Dessa forma, Kellner (2000, p. 126-127) afirma:

(...) que a linguagem do filme não possui uma analogia exata em acontecimentos sociais, nem o discurso do cinema existe como uma imagem paralela de eventos reais. Ao invés, os filmes pegam o material cru da história social e dos discursos sociais e os transforma em produtos que são por si mesmos eventos históricos e forças sociais. Filmes, assim podem fornecer informações sobre a 'psicologia' de uma era e suas tensões, conflitos, medos,

\footnotetext{
${ }^{1}$ Internet Movie Database (IMDb), disponível em:< http://www.imdb.com.br/>.
} 
e fantasias, mas eles o fazem não como uma simples representação ou espelho de uma realidade social extra-cinemática. Ao invés, os filmes refratam os discursos sociais e satisfazem formas cinemáticas específicas que engajam espectadores em um processo ativo de construção de significado.

\subsection{Objetivo geral}

O artigo busca comparar como as cores do cinema expressam a imagem da gastronomia antes do boom gastronômico (década de 90) e após (anos 2000). O período escolhido é relevante por se tratar de um período curto de tempo (20 anos) em que a gastronomia conquistou um evidente destaque na população. A comparação da apresentação da gastronomia através da paleta cromática explicará como a representação da gastronomia através da sétima arte evoluiu e como isso atinge o subconsciente do espectador com o uso da psicologia de cores, já que as paletas de cores usadas em filmes evocam no imaginário do telespectador uma localização da história no tempo, imergindoo na atmosfera desejada.

\subsection{Objetivos específicos}

- Observar a expressão da gastronomia através do cinema;

- Pesquisar como as cores são utilizadas para representar a gastronomia na cozinha, no preparo de alimentos e comensalidade e atingir o subconsciente do telespectador, associando-as aos sentimentos e o motivo de sua aplicação durante as cenas específicas;

- Comparar os resultados pré e pós o boom gastronômico.

\section{CORES E SEUS ASPECTOS FÍSICOS, FISIOLÓGICOS E CULTURAIS}

Estudar a percepção da cor não é tarefa simples e é requisito básico para estudantes de design gráfico, design de interiores, arquitetura, entre outros. A aplicação da cor em projetos não pode ser realizada de maneira puramente intuitiva. O estudo é múltiplo, interdisciplinar e complexo (SILVEIRA, 2015).

Witter e Ramos (2008) definem cor como sendo uma sensação provocada pelos órgãos de visão, sendo que os objetos deixam de manifestar cores com a ausência de luz, mas continuam sensíveis ao tato.

Peter (2014) afirma que cor é um elemento complexo resultando da interação entre os olhos e a luz, sendo assim, um objeto não possui cor e sim um resultado da interação da luz e dos componentes coloridos do objeto, sendo ela subjetiva e diferente para cada indivíduo. 
Para Aristóteles (384 - 322 a.C.) a cor tem como origem o enfraquecimento da luz branca, ou seja, as cores têm origem com a interação da luz com o escuro. Em 302 a.C., Euclides elaborou "Óptica e Catóptrica" estudando a refração da luz. Um segundo conceito surgiu da relação entre luz e cor sendo a cor uma qualidade da luz sobre os corpos (GUIMARÃES, 2001).

Isaac Newton (1643 - 1727), em 1672, analisou um feixe de luz branca que incidiu num anteparo após passar por um prisma, observando um espectro colorido com as mesmas cores presentes no arco-íris, concluindo que a luz branca é uma mistura heterogênea de todas as cores. Num segundo experimento, foi adicionado um pequeno furo no anteparo que permitia a passagem de um feixe de uma única cor, que atravessava um outro prisma e era refratada em um segundo anteparo. Girando o primeiro prisma foi possível alterar a cor refratada pelo segundo prisma, ou seja, as cores não eram qualificações da luz (SILVA, 1996).

Thomas Young $(1773$ - 1829) revisitou o estudo de Newton e descobriu que das sete cores apontadas por ele como primárias, apenas 3 (vermelho, verde e azul) quando somadas resultavam na cor branca. A teoria de Young foi baseada através da visão e do olho humano, que contém três cones receptores sensíveis a luz, um para cada uma das cores primárias (SCHWNDLER, 2015).

Johann Wolfgang van Goethe (1749 - 1832), autor de "A Doutrina das Cores" (1810) possuía pensamentos divergentes de Newton. Em seu trabalho concluiu que a luz era o ser mais simples, indivisível e homogêneo conhecido, sendo um fenômeno que existia além da física, recebendo influências da fisiologia e da cultura humana, além de apresentar dois outros elementos na construção do conceito de cor: "sentido da visão" e "sensibilidade" ou nosso "ânimo" (SILVEIRA, 2015; GUIMARÃES, 2001).

Porém, a afirmação que o branco é o resultado da somatória de outras cores foi feita por Leonardo da Vinci antes de Newton. A teoria cromática dos tempos modernos baseia-se nessa descoberta. Para da Vinci, os olhos eram passivos, isto é, recebiam raios ao invés de emiti-los, inaugurando, assim, o pensamento de que a percepção visual cromática é elaborada a partir de informações do meio em que vivemos (SILVEIRA, 2015, p. 23).

Guimarães (2010) explica que o processo visual se inicia com os olhos humanos recebendo informações luminosas de objetos que estão por perto, três cones interpretam essas energias e possibilitam a distinção das cores.

O modo de enxergar é subjetivo. Um indivíduo capta detalhes do mundo exterior de acordo com seus sentidos que são sempre os mesmos em todos os seres humanos, entretanto sempre há uma diferença biológica. A cultura produz estados de sensibilidade desiguais, sentidos distintos e incontroláveis (SCHWENDLER, 2015). 
Schwendler (2015), Farina, Bastos e Perez (2011) verificam que a cor invade a subjetividade e o comportamento do homem. A cultura, vivências em comum e as experiências pessoais individuais interferem a interpretação das cores, enraizadas na linguagem e no pensamento humano desde a infância. Ela não sofre barreiras pela língua, podendo ter sua mensagem compreendida até mesmo por analfabetos.

Dessa forma, pode-se analisar melhor a presença das cores na arte e no audiovisual, identificando o que querem dizer com o uso de determinada cor e o sentimentalismo transmitido por ela.

\section{HISTÓRIA DA COR E DE FILMES GASTRONÔMICOS NO CINEMA}

Uma das características do cinema é a linguagem não verbal e a estética da imagem, o filme requer elementos cuidadosamente selecionados para dar sentido à história. Através da imagem apresenta-se outros elementos que sustentam a narrativa: cenário, figurino e personagens (SCHWENDLER, 2015).

Hércules (2012) acredita que tanto para a pesquisa quanto para a realização cinematográfica, a cor deve ser aceita como elemento integrante da narrativa e não como dado supérfluo, pois criam significados, sensações ou estados emocionais. Schwendler (2015) concorda, afirmando que a concepção de espaços é um processo importante na direção de arte cinematográfica, sendo a cor uma de suas particularidades inerentes. Estando clara a participação e o significado dela dentro das cenas, o espectador conseguirá compreender seu uso pelo diretor, mesmo sendo subjetivo.

Neves (2015) afirma que desde a criação do cinema, em 1895 pelos irmãos Lumiére, a ambição pelas cores se manifestava. No mesmo ano, Thomas Edison havia feito uma película de poucos segundos, pintada a mão e chamada de Anna Belle Serpentine Dance. Quatro anos mais tarde, os próprios irmãos Lumiére apresentavam o Serpentine Dance, ambos mostrando mulheres dançando com tecidos que mudavam de cores.

Ressaltando que essas primeiras películas retratavam a vida da burguesia francesa, além da cena do bebê havia a famosa cena do trem em "L'arrivée d'um Train à La Ciotat" e a de um jardineiro regando flores em "L'Arrouseur Arrosé3". Em 1896, os críticos russos não foram tão eufóricos quanto os franceses: “(...) estive no Reino das Sombras (...) É um mundo desprovido de

\footnotetext{
${ }^{2}$ A Chegada do Trem na Estação, Auguste e Louis Lumière, 1896. Fonte:< http://www.imdb.com/title/tt0000012/>, acesso em: 26 fev, 2018.

${ }^{3}$ O Regador Regado, Louis Lumière, 1897. Fonte:< http://www.imdb.com/title/tt0000136/>, acesso em: 26 fev, 2018.
} 
som e cor. Tudo nele (...) encontra-se mergulhado num cinza monótono... Não se trata de vida, mas de sombra (...)" (LEYDA, 1972, apud NEVES, 2015, p. 21-27).

Os anos 1930 trouxeram as cores ao cinema, com Becky Sharp, em 1935, realizado pelo americano Rouben Mamoulian, o primeiro filme com cores. Entretanto, a marca norte-americana Technicolor havia desenvolvido em 1915 a tecnologia de captação de cores através da sobreposição de imagens em duas películas: uma verde e a outra vermelha. Era impossível, com este avanço, a captação do azul e do branco, mas foram lançados filmes como Os Dez Mandamentos de Cecil B. DeMille em 1923 e O Fantasma da Ópera de Rupert Julian e Ben-Hur de Fred Niblo em 1925 (NEVES, 2015).

A Technicolor foi responsável por inserir no mercado o primeiro processo realmente industrial de cor, causando uma evolução significativa na qualidade do cinema colorido. Houve relutância da parte de alguns produtores em aceitar as cores, pois tinham medo que elas pudessem consumir toda a atenção e surgiram movimentos que tentaram inverter a tendência e impulsionar o cinema preto e branco, como o Cinema Noir e o Nouvelle Vague (ABREU; ANDRADE, 2016; NEVES, 2015).

A Technicolor impôs diversas restrições ao uso das cores, bloqueando a criatividade e desperdiçando a linguagem fílmica. A cor deveria obedecer a padrões realistas de composição, ou seja, utilizar tons intermediários ao invés de cores fortes e uniformes (HÉRCULES, 2012; ABREU; ANDRADE, 2016).

A cor deixou de ser direcionada exclusivamente ao realismo quando os diretores compreenderam que elas não precisavam ser realistas, devendo ser utilizadas em função dos valores, implicações psicológicas e dramáticas das tonalidades. Para Godard, as cores eram um novo modo de refletir as possibilidades estéticas do cinema, por isso abusou do uso de cores primárias em Pierrot le fou 4 , abusando das cores da bandeira francesa (ABREU; ANDRADE, 2016; HÉRCULES, 2012).

Um longo debate ainda merece ser posto, pois a cor é severamente descartada em muitas análises fílmicas, vista com preconceito, como se fosse um elemento superficial. No entanto, Pierrot le fou de Jean-Luc Godard e Le bonheur ${ }^{5}$ de Agnès Varda (1965) confirmam a premissa de que os elementos visuais coloridos abrem a análise fílmica para um campo de profunda reflexão sobre os meios de construção do cinema e atesta que a cor pode traduzir conceitos e debates não expostos no plano da narrativa. A obra de Godard, amplamente estudada e mapeada nas mais diversas diretrizes de análise, merece uma reconsideração hoje, justamente por associar a cor aos mais diversos horizontes: plástico, ideológico, societal. De fortuna crítica reduzida, a obra de Agnès Varda apresenta maiores estudos do ponto de vista das

\footnotetext{
${ }^{4}$ O Demônio das Onze Horas, Jean-Luc Godard, 1965
}

${ }^{5}$ As Duas Faces da Felicidade, Agnès Varda, 1965 
relações de gênero, mas muitos deles descartam o trabalho plástico da cineasta (HÉRCULES, 2012, p. 1312).

Ao tratar sobre a origem do cinema, Yasoshima (2012) e Neves (2015) relatam a respeito da primeira sessão pública de projeções de imagens apresentadas pelos irmãos Lumiére, ocorrida no dia 28 de dezembro de 1895 e que é reconhecida como o marco inicial do cinema. Nesta sessão foram apresentados dez pequenos filmes, dentre eles estava o primeiro filme-documentário considerado como gastronômico: Le Repas du Bébé (O Almoço do Bebê), o qual retratava Auguste Lumière e sua esposa alimentando seu filho durante o café da manhã em um jardim de uma grande mansão. Nogueira (2008) enfatiza que a cena da mesma obra é absolutamente prosaica e que o ato da alimentação haveria de ser repetido vezes sem conta, com pequenas variações, nos filmes caseiros que o futuro se encarregaria de produzir.

Yasoshima (2012), ainda aponta o fato dessa primeira sessão de projeção de imagens ter ocorrido em uma exibição pública no Grand Café de Paris, um restaurante tradicional francês localizado no Boulevard de Capucines, área onde se concentram diversas casas de espetáculos. Montoro (2004) também faz essa observação e salienta ainda a interação do próprio espaço físico do cinema com a comida, ao analisar que atualmente as exibições de filmes ocorrem em shoppings ou em pequenos espaços, onde cardápios são expostos próximos aos cartazes de filmes.

Assim, de acordo com as afirmações de Yasoshima (2012) e Montoro (2004), pode-se concluir que a relação entre cinema e gastronomia é longínqua e duradoura, estabelecendo-se desde a origem do cinema e permanecendo na contemporaneidade.

Para compor sua pesquisa, Yasoshima identifica 120 filmes que podem ser considerados como gastronômicos. Da década de 30 até os anos 80 haviam sido lançados apenas 12 filmes com essa temática, entretanto, do começo deste século até a data de sua pesquisa (2012), já haviam sido lançados 64 filmes $^{6}$ (ver quadro 1 ).

\footnotetext{
${ }^{6} \mathrm{O}$ artigo de José Roberto Yasoshima (2012), intitulado "Gastronomia na tela: as representações da comida no cinema" foi muito importante no desenvolvimento deste trabalho. Primeiramente ele classifica o gênero de filmes gastronômicos como filmes cujo enredo principal gire em torno da temática da comida, da comensalidade, das suas relações sociais e antropológicas. Os valores exatos são questionáveis, mas o interessante de sua pesquisa é o apontamento feito sobre a quantidade porcentual.
} 
Quadro 1 - Produção de Filmes Gastronômicos.

\begin{tabular}{c|c|c}
\hline Década & Quantidade & Porcentual \\
\hline $1931-1940$ & 1 & $0,8 \%$ \\
\hline $1941-1950$ & 1 & $0,8 \%$ \\
\hline $1951-1960$ & 1 & $0,8 \%$ \\
\hline $1961-1970$ & 3 & $2,5 \%$ \\
\hline $1971-1980$ & 6 & $5 \%$ \\
\hline $1981-1990$ & 11 & $9,2 \%$ \\
\hline $1991-2000$ & 31 & $25,8 \%$ \\
\hline $2001-2010$ & 58 & $48,3 \%$ \\
\hline $2011-2012$ & 8 & $6,7 \%$ \\
\hline \multicolumn{2}{|c|}{ Fonte: Yasoshima (2012, p. 303) }
\end{tabular}

De acordo com a pesquisa de Yasoshima (2012) e Chenille (2004), o gênero de filmes gastronômicos aumentou em quantidade significativa na última década, o que pode possibilitar um profícuo campo de estudo. Abreu e Andrade (2016) discursam sobre como a popularização do cinema impulsionou seu avanço. O público queria novas perspectivas, com elementos da realidade, em prol da manutenção do interesse. Essas inovações construíram uma linguagem fílmica que é formada por todos os elementos: figurino, enquadramento, iluminação, cores, sons. Cada elemento trazendo significados próprios, e atuando em conjunto tornam-se capazes de transmitir sensações e sentimentos aos telespectadores.

\section{APLICAÇÃO DAS ANÁLISES}

\subsection{Análise conotativa}

Pode-se ter uma pequena noção de associação de cores com objetos culturais e significados subjetivos conferindo o quadro 2. O quadro 3 apresenta normas da ABNT referente ao uso de cores na segurança do trabalho, tendo sido estudado componentes psíquicos, socioculturais e fisiológicos:

Quadro 2 - Sensações visuais, Objetos e Significados

\begin{tabular}{l|l|l}
\hline \multicolumn{1}{c|}{ Sensações visuais } & \multicolumn{1}{|c}{ Objeto } & \multicolumn{1}{c}{ Significado } \\
\hline Branco & Vestido de Noiva & Pureza \\
\hline Preto & Noite & Negativo \\
\hline Cinza & Manchas imprecisas & Tristeza, coisas amorfas \\
\hline Vermelho & Sangue & Calor, dinamismo, ação, excitação. \\
\hline Rosa & Enxoval de bebê (menina) & Garça, ternura \\
\hline Azul & Enxoval de bebê (menino) & Pureza, fé, honradez \\
\hline \multicolumn{2}{|c}{ Fonte: Farina; Bastos e Perez (2006, p. 87) }
\end{tabular}


Quadro 3 - Sensações visuais e utilização

\begin{tabular}{l|l}
\hline \multicolumn{1}{c|}{ Sensações Visuais } & \multicolumn{1}{|c}{ Utilização } \\
\hline Azul & Controles de equipamentos elétricos \\
\hline Laranja & $\begin{array}{l}\text { Partes móveis e mais perigoas de máquinas e } \\
\text { equipamentos, faces externas de polias e engrenagens }\end{array}$ \\
\hline Vermelho & $\begin{array}{l}\text { Equipamentos de proteção contra incêncios ou de } \\
\text { combates contra incêndio }\end{array}$ \\
\hline Verde & Caixa de socorros de urgência, avisos, boletins, etc. \\
\hline Branco & Faixas indicativas de sentido de circulação \\
\hline Preta & Coletores de resíduos \\
\hline
\end{tabular}

\subsection{Análise diacrônica}

\subsubsection{Análise diacrônica de cenas que retratam o espaço da cozinha}

Na utilização de filmes como objetos de pesquisa, segundo Ricci (2003) e Kellner (2000), há de se ter o devido cuidado, pois os filmes não possuem "analogia exata" entre a representação nas telas e a realidade.

Para o presente artigo foram escolhidos os filmes relacionados no quadro 4.

Quadro 4-Filmes seleciondos

\begin{tabular}{l|c|l|c|c}
\hline \multicolumn{1}{c|}{ Filme } & Ano & \multicolumn{1}{c|}{ Direção } & $\begin{array}{c}\text { Nota no } \\
\text { IMDb }\end{array}$ & Bilheteria \\
\hline Julie \& Julia & 2009 & Nora Ephron & 7,0 & $\$ 94.125 .426$ \\
\hline Sem Reservas & 2007 & Rober Scott Hicks & 6,3 & $\$ 43.107 .979$ \\
\hline Mais Estranho que a Ficção & 2006 & Marc Foster & 7,6 & $\$ 40.137 .776$ \\
\hline Vatel - Um Banquete para o Rei & 2000 & Roland Joffé & 6,6 & $\$ 49.464 .400$ \\
\hline Como água para Chocolate & 1992 & Alfonso Arau & 7,2 & $\$ 21.665 .500$ \\
\hline Tomates Verdes Fritos & 1991 & Jon Avnet & 7,7 & $\$ 82.418 .501$ \\
\hline \multicolumn{2}{r|}{ Fonte: Elaborado pelo autor. }
\end{tabular}

Analisando, portanto, as cores contidas nesses aspectos, uma sequência das cenas foi criada, identificando as cores mais presentes. Para auxílio na definição da paleta cromática foi utilizado o aplicativo on-line Adobe Color $^{7}$ (figura 1), que ajuda a identificar rapidamente a paleta cromática de 5 cores de uma imagem e ainda oferece informações sobre tipo de contraste (OLIVEIRA, 2016, p. 4648). As capturas de tela foram transferidas para o software Adobe Photoshop CC 2015, onde a ferramenta "Conta-gotas" auxiliou na captação e identificação das cores mais presentes.

Foram analisadas as cores das cenas, unificando-as caso não houvesse prejuízo. As cores foram estudadas em bibliografia e catálogos cromáticos. Assim como Oliveira (2016), em seu

\footnotetext{
${ }^{7}$ Disponível em: <https://color.adobe.com/create/image/>. Acesso em: 07 mar. 2018. 
trabalho de conclusão de curso intitulado: "Desenvolvimento de Guia Cromático com Foco no Cinema do Terror", de 2016, avançou com o uso das análises conotativa e diacrônica da "Metodologia Projetual e Aplicação Cromática" de Braga, Kunrath e Medeiros (2008), sendo o primeiro levantamento de informações sobre cores descritas em seu significado ampliado, dentro de conceitos comuns, específicos ou subjetivos e o segundo o levantamento de material histórico, relativo ao uso de cores naquele produto, filmes neste caso, com finalidade de detectar, conhecer e compreender mudanças tecnológicas, culturais e da percepção das pessoas em relação às cores.

Figura 1 - Página do Adobe Color analisando a paleta cromática de Julie \& Julia.

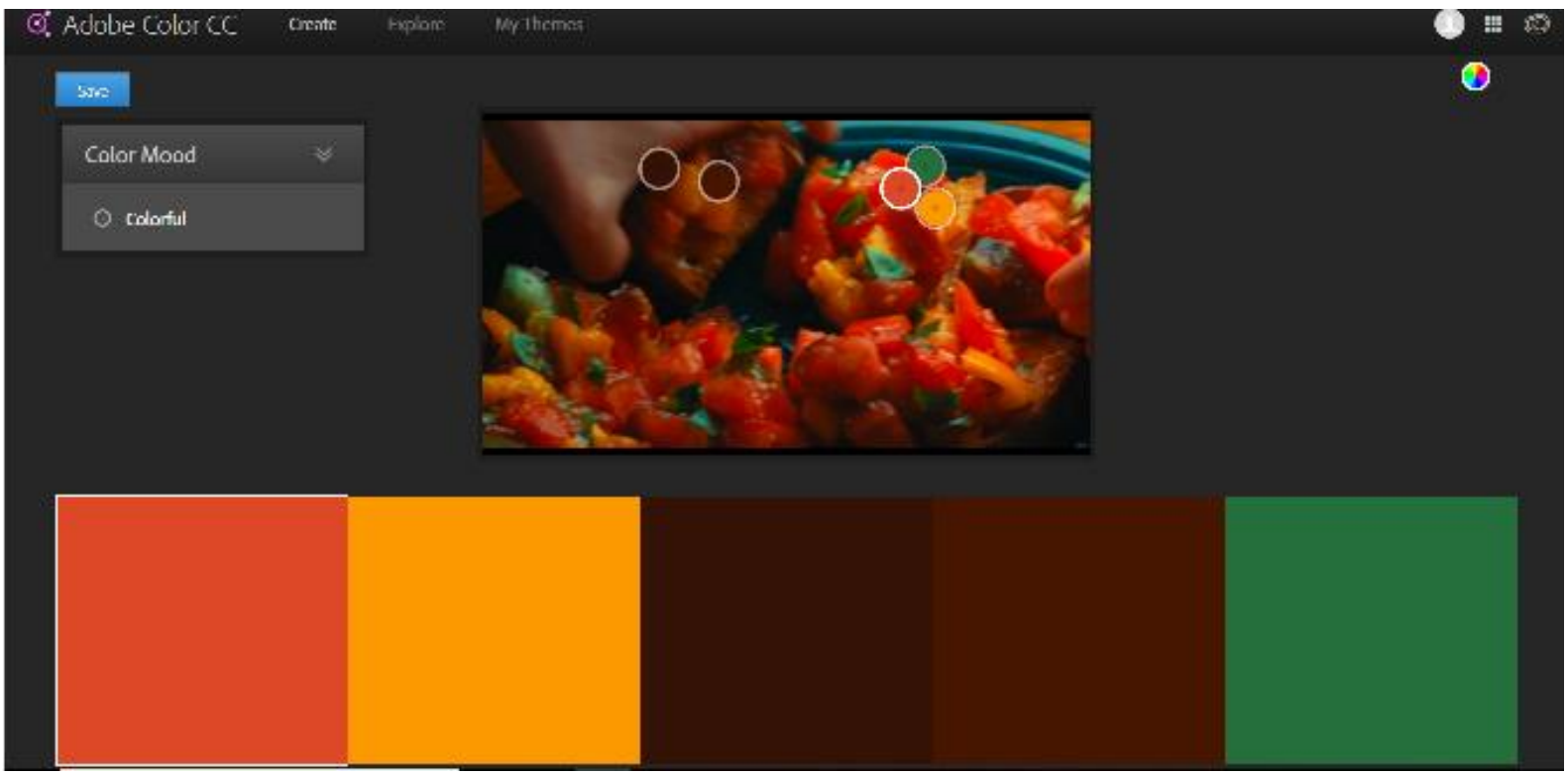

Fonte: Elaborado pelo autor

Para a realização da pesquisa diacrônica, no âmbito de paleta cromática aplicada às cenas gastronômicas, primeiramente será feita uma divisão entre as cenas que se passam na cozinha, com o preparo de alimentos e da comensalidade. Em seguida será feita uma linha do tempo com os filmes e a comparação entre eles, em busca de mudanças na representação. ${ }^{8}$

Ramos $(2009$, p. 5) afirma que a história do cinema trabalha com a dimensão diacrônica da arte cinematográfica, entendendo diferentes períodos e movimentos. Concordando com Saussure (2002) "é sincrônico tudo quanto se relacione com o aspecto estático da nossa ciência; é diacrônico tudo que diz respeito às evoluções" (apud SABTKE, 2013, p. 9) e Guedes (2009, p. 4) "a redefinição científica de significados lexicais anteriores".

\footnotetext{
${ }^{8}$ Braga, Kunrath e Medeiros (2008); Ramos (2009); Guedes (2009) e Hélen (2016) abordam a análise diacrônica como um estudo histórico, por isso foi optado por realizar uma análise cronológica da evolução da paleta cromática nos 6 filmes escolhidos.
} 
Na figura 2 pode-se observar uma cena aleatória da cozinha dos três primeiros filmes ordenados cronologicamente por ordem de lançamento e a respectiva paleta cromática alinhada ao seu lado.

O primeiro filme, Tomates Verdes Fritos (1991), não retrata com profundidade a cozinha. Os cortes são focados nos ingredientes in natura e na fritura dos tomates verdes. A cozinha do café aparece poucas vezes por inteira e possui uma paleta cromática escura, porém de iluminação natural (marrom, bege, verde). Já Evelyn nunca efetivamente é vista cozinhando, a comida sempre está servida e tudo está muito limpo. Quando o ambiente aparece completo, Evelyn está com uma cama elástica azul, que contrasta com as cores escuras (marrom) e redireciona a atenção do espectador em relação à cozinha.

Figura 2 - Quadros acima: cozinha respectivamente do café e de Evelyn (Tomates Verdes Fritos, 1991); abaixo à esquerda está a cozinha da mãe de Tita (Como Água para Chocolate, 1992) e embaixo à direita o açougue da cozinha de Vatel (2000).

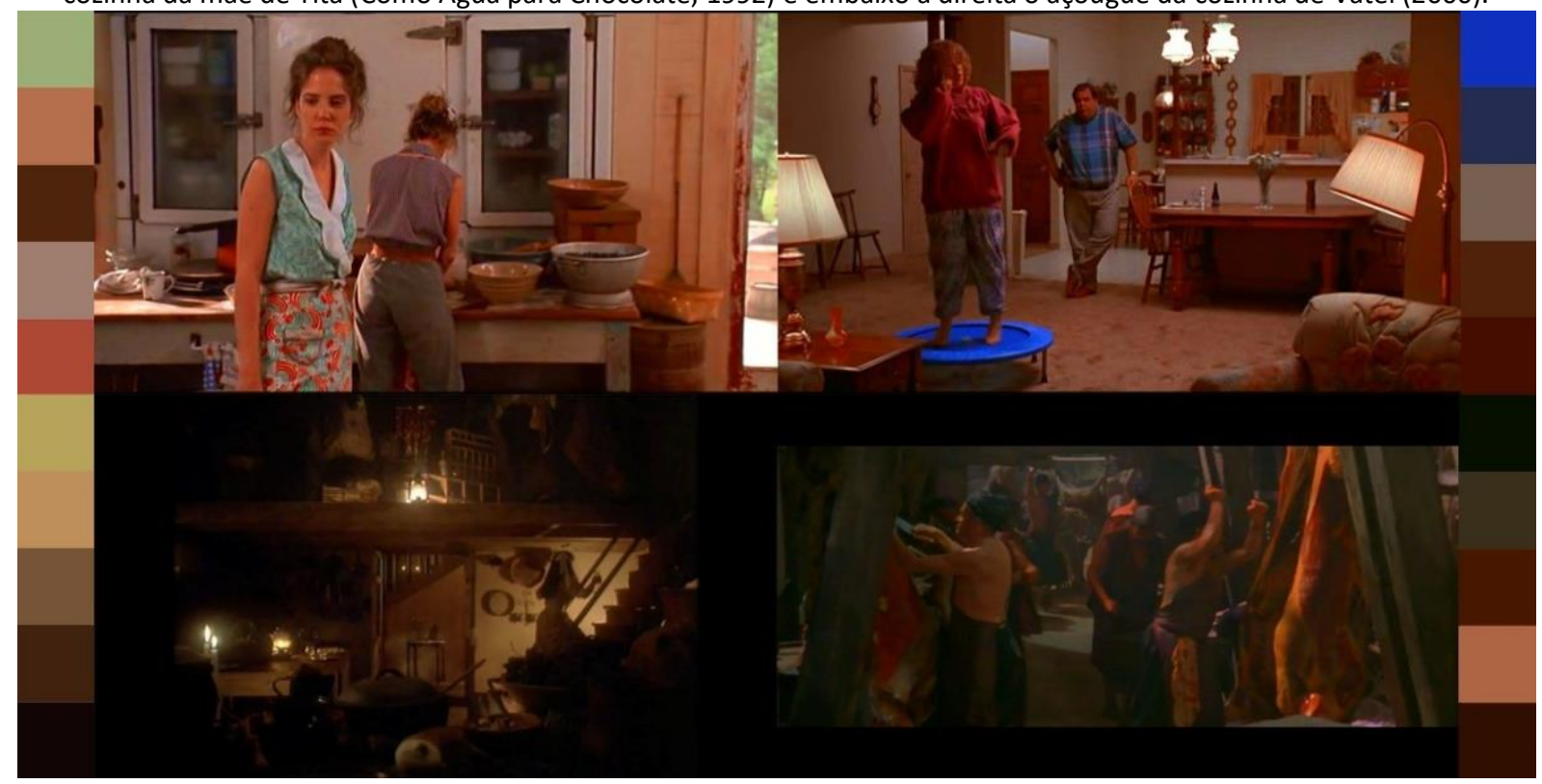

Fonte: elaborada pelo autor.

Em Como Água para Chocolate (1992) e Vatel - Um banquete para o Rei (2000), a cozinha está presente em uma quantidade perceptivelmente maior e é representada com a paleta cromática bem escura (preto, marrom, cinza).

No filme Mais Estranho que Fiç̧ão (2006), primeiro analisado cronologicamente de 2001 a 2010, a confeitaria de Ana é anexa ao salão. O primeiro encontro e conflito de Ana e Harold acontece nessa cozinha de paleta cromática de tons vermelhos e verdes além de diálogos importantes para o desenvolvimento dos personagens. Mais tarde é apresentada a cozinha pessoal de Ana de cor verdeclara, contrastando com cores escuras. 
A presença da cozinha profissional em Sem Reservas (2007) é constante além da cozinha da casa de Kate também ser apresentada, sempre com a presença do branco e cores quentes.

As cozinhas de Julie \& Julia (2009) são cenários de desenvolvimento da trama. Há a participação de verde, amarelo, laranja e azul, lembrando que a paleta cromática da cozinha de cada uma é diferente por retratar personagens de personalidades completamente diferentes.

Ao relacionar as películas de ambas as décadas, os filmes de 2001-2010, exemplificados na figura 3, nota-se como o cinema passou a retratar a cozinha com cores mais quentes e vivas, com presença de cores não utilizadas nas películas da década anterior como: amarelo, laranja, verde, azul e vermelho. Também passa a ser utilizado o branco quando Julia está na Le Cordon Bleu e na cozinha de Kate.

Figura 3 - Quadro superior esquerdo: Confeitaria do filme Mais Estranho que Ficç̧ão (2006); quadro superior direito: Kate de Sem Reservas (2007); quadros inferiores: Julie \& Julia (2009). Todos com a respectiva paleta cromática ao seu lado.

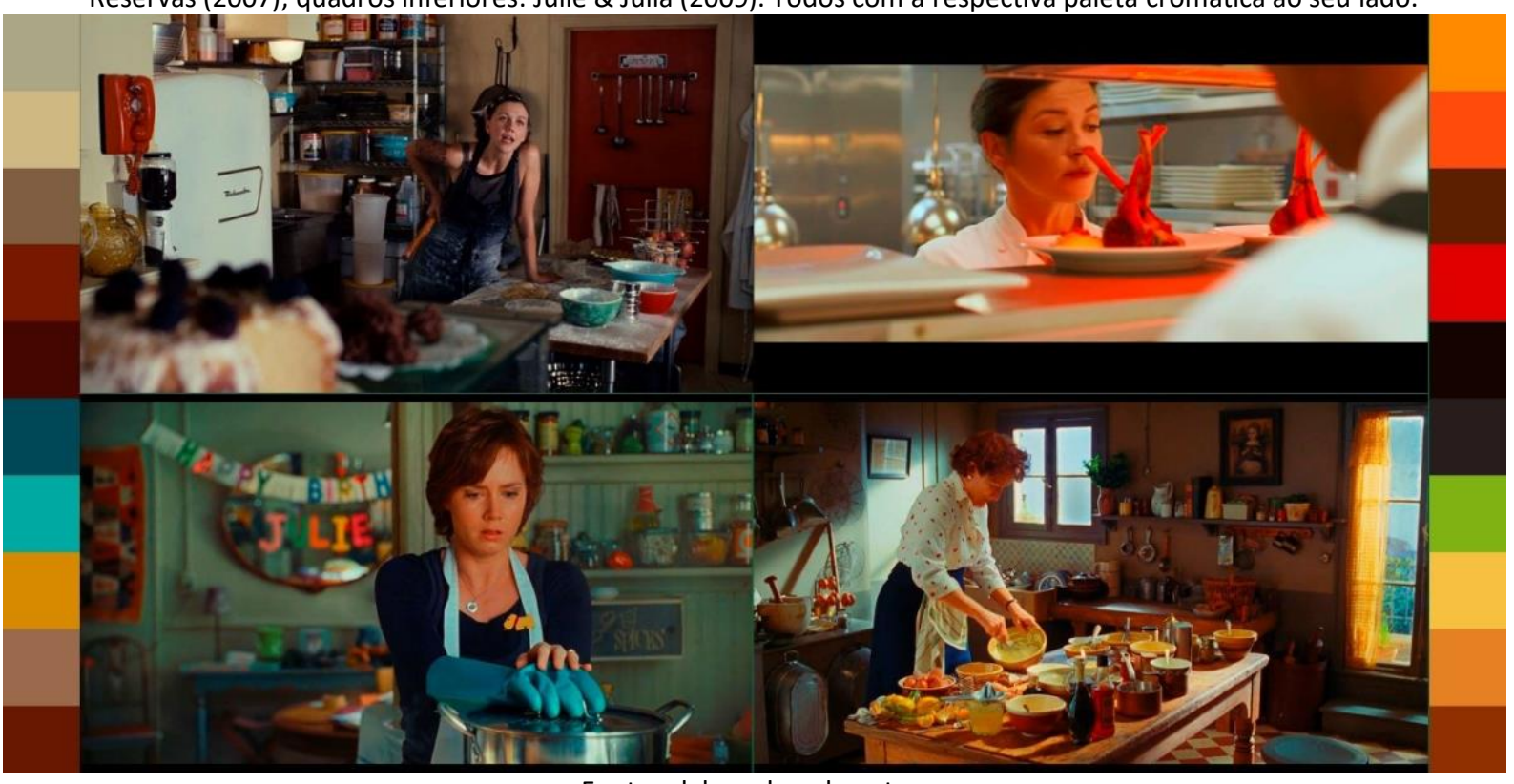

Fonte: elaborada pelo autor.

\subsubsection{Análise diacrônica de cenas que retratam o cozinhar}

Serão abordadas as cenas que possuam preparo de alimentos, com foco nos ingredientes e na produção, analisando a paleta cromática em busca de transformações ocorridas ao longo dos anos.

Em Tomates Verdes Fritos (1991) observa-se a apresentação de vários ingredientes in natura, os tomates verdes empanados sendo fritos e o churrasco na área externa. Ao observar a paleta cromática disposta na figura 4 é possível observar as cores escuras no preparo dos tomates e no churrasco, como o marrom e o cinza, contendo a presença do verde na área externa - também 
utilizado em diversas outras cenas não-gastronômicas. O alimento in natura é retratado com cores escuras (marrom e preto) contrastando com claras (vermelho e branco).

Figura 4 - Personagens cozinhando em Tomates Verdes Fritos (1991).

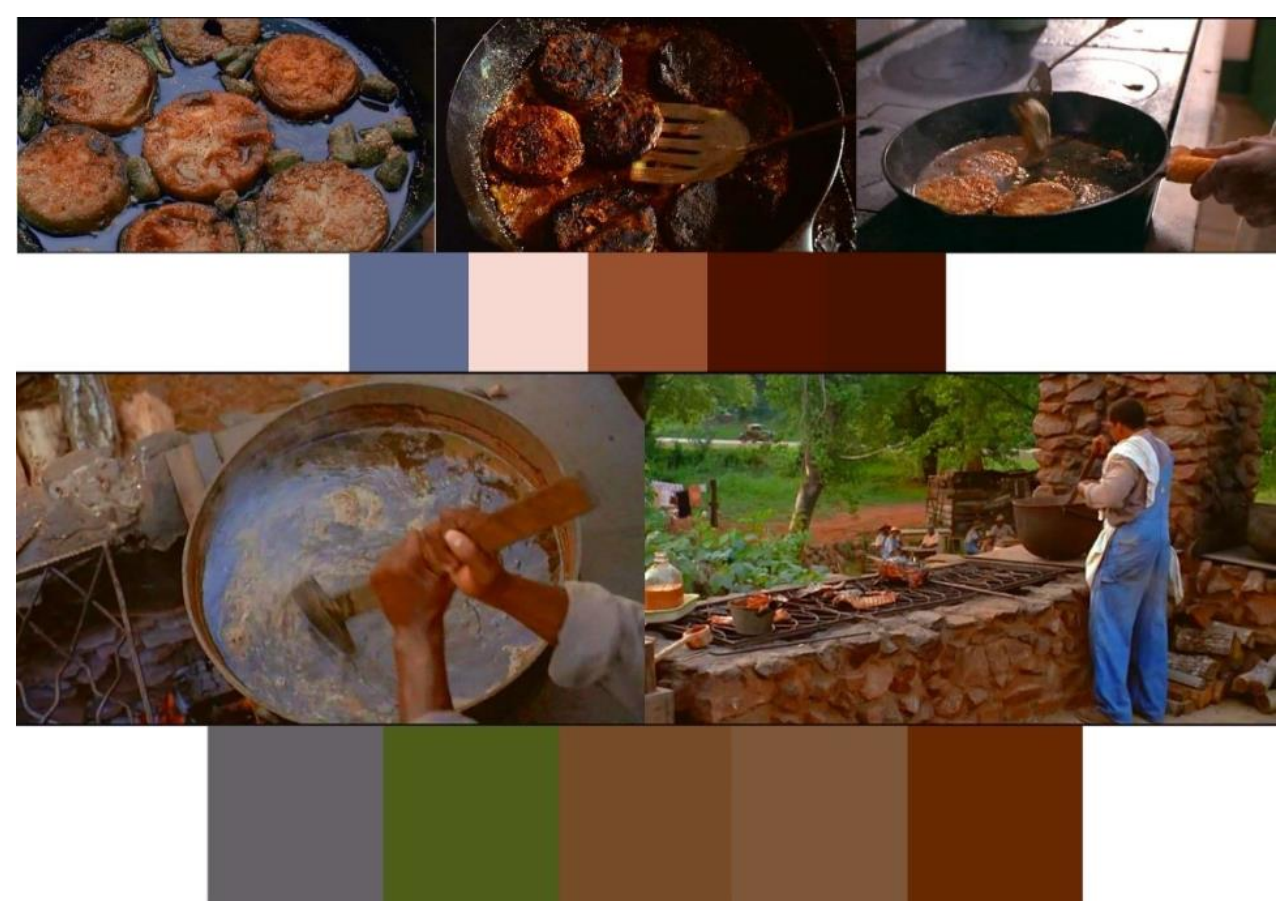

Fonte: elaborado pelo autor.

Em Como Água para Chocolate (1992) Tita está sempre cozinhando alguma coisa diferente, há cenas com foco na massa do bolo sendo feita, nas mãos de Tita amarrando as patas da codorna para cima, adicionando o tempero final ao prato pronto, abrindo massa de pão, etc. enquanto diálogos importantes para o roteiro ocorrem. Há a presença do vermelho nas pétalas das rosas, e a repetição das cores escuras e na figura 5 é possível observar cores escuras novamente (marrom) com uma fraca presença do branco, agregado à iluminação das janelas.

Vatel - Um Banquete para o Rei (2000) aborda os problemas de uma grande cozinha da corte francesa: atraso na entrega de alimentos, falta de ingredientes, utensílios quebrados por mal transporte. Em geral, a paleta cromática é escura (preto, marrom) e sempre há pouca iluminação, nas cenas em que se cozinham ao exterior é notado o verde (Figura 5). 
Figura 5 - Nos quadros de cima Tita cozinha em Como Água para Chocolate (1992) e abaixo estão personagens de Vatel - Um Banquete ao Rei (2000).

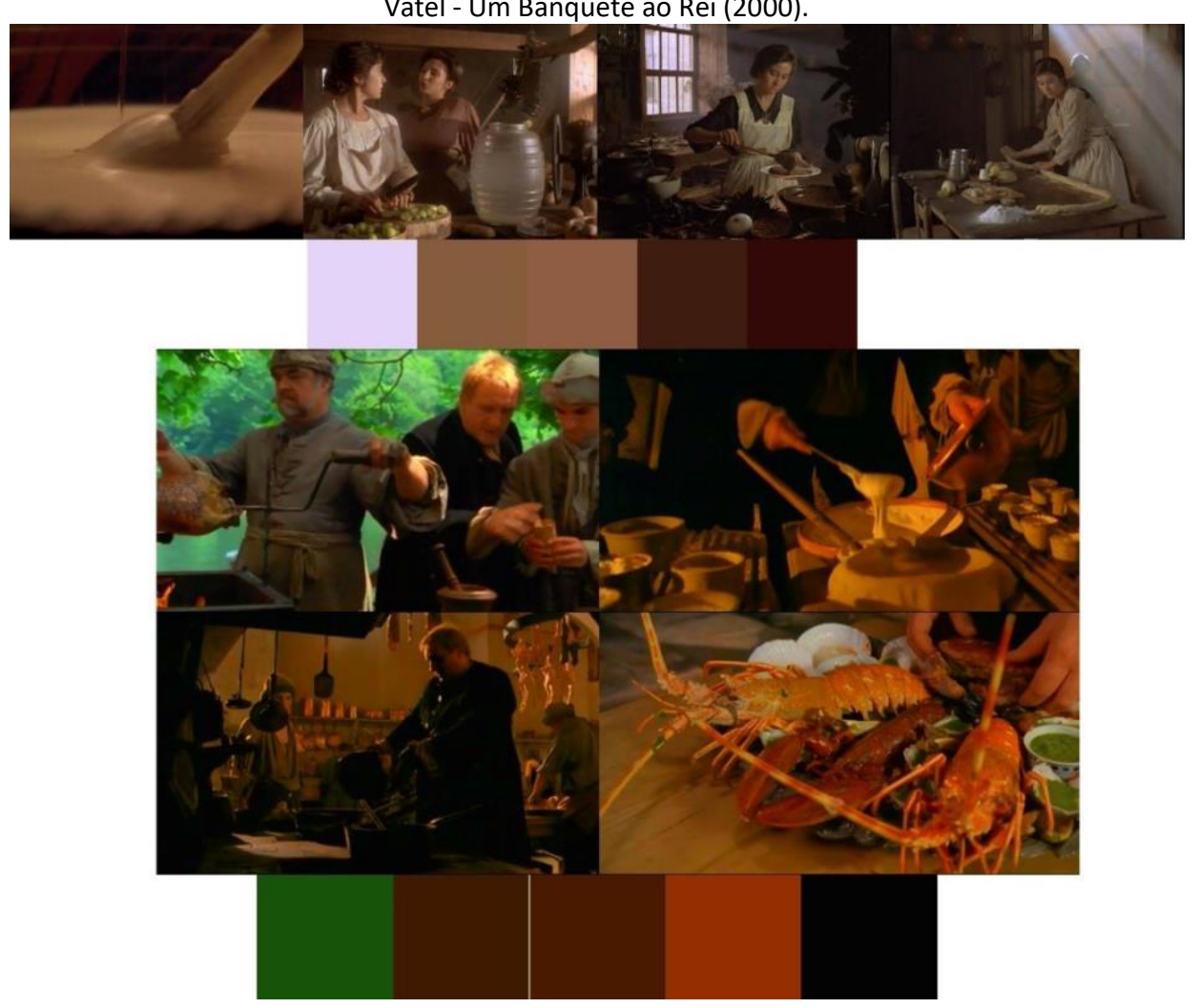

Fonte: elaborado pelo autor.

Figura 6 - Quadros de cima, cenas de Julie \& Julia (2009); abaixo há cenas de Sem Reservas (2007.)

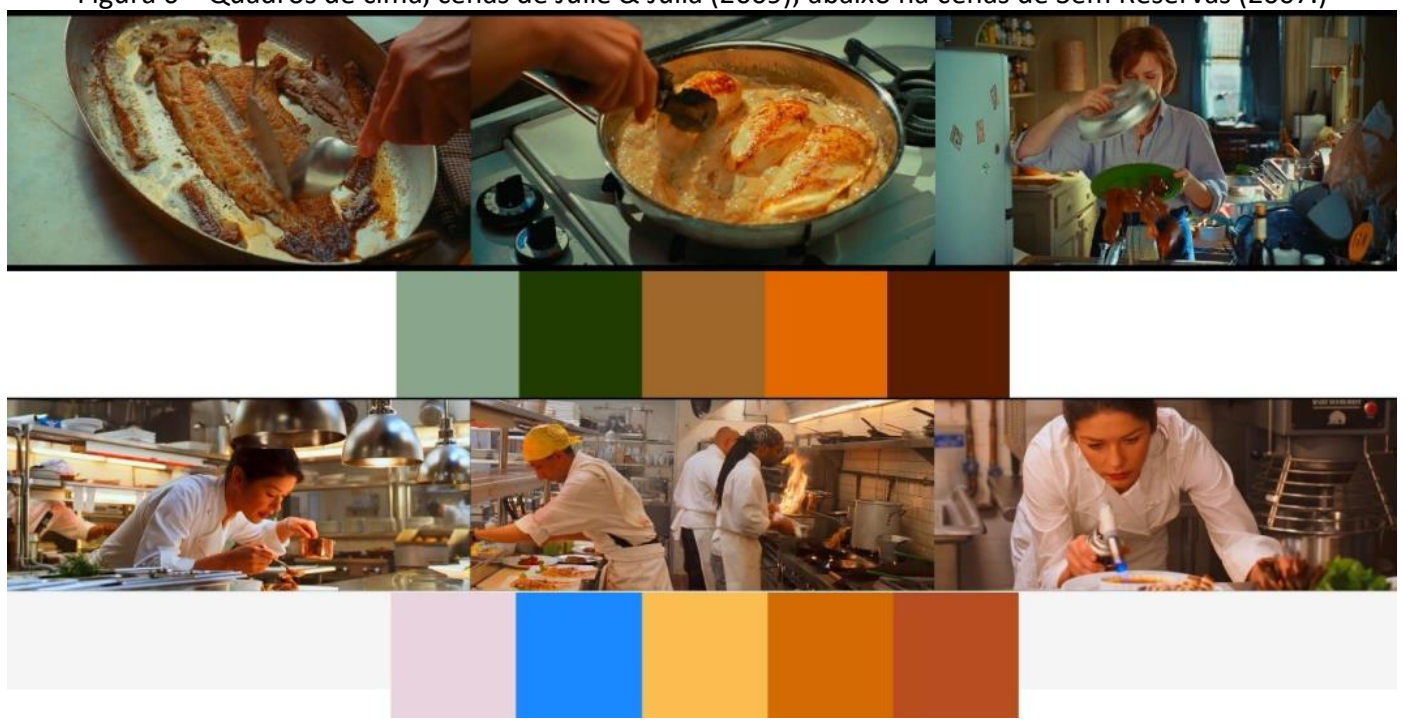

Fonte: elaborado pelo autor.

Mais Estranho que Fiç̧ão (2006) não apresenta os personagens efetivamente cozinhando, entretanto há diálogos que ocorrem na padaria enquanto Ana assa cookies ou abre massas. Já nos outros dois filmes escolhidos dos anos 2000 há inúmeras cenas em que os personagens cozinham.

A figura 6 contém exemplos de personagens cozinhando em filmes mais novos, ao comparála com a figura 5, podemos observar como as cores ficam mais fortes e alegres nas películas mais atuais. Pedrosa (2008) as classifica como cores quentes e frias. 
De fato, chamamos de quentes as cores que integram o vermelho, o laranja e pequena parte do amarelo e do roxo; e de "frias" as que integram grande parte do amarelo e do roxo, o verde e o azul. As cores quentes parecem nos dar uma sensação de proximidade, calor, densidade, opacidade, secura, além de serem estimulantes. Em contra-posição, as cores frias parecem distantes, leves, transparentes, úmidas, aéreas, e são calmantes. (FARINA; BASTOS; PEREZ, 2011, p. 86).

4.2.3 Análise diacrônica de cenas que retratam a comensalidade

A comensalidade é definida como o ato de comer e beber juntos ao redor de uma mesa, sendo a mesa um ritual que representa a família, comunhão e irmandade, sendo também local de tensão e conflitos familiares, podendo haver silêncios perturbadores que revelam um mal-estar coletivo (BOFF apud YASOSHIMA, 2012, p. 306).

Definida a comensalidade, pode-se observar sua presença em todos os filmes escolhidos. A figura 7 contém alguns exemplos de comensalidade dos filmes da década de 90 com a respectiva paleta cromática, que possui uma dominância de cores escuras (preto, marrom, cinza), mas também possui cores mais alegres que as retratadas na cozinha e durante serviço dos mesmos filmes (azul, vermelho, verde, amarelo).

As figuras 8 e 9 são exemplos dos filmes restantes (2001 - 2010) com cores mais marcantes ainda e a presença do roxo, além das já utilizadas durante a comensalidade (vermelho, azul, amarelo). 
Figura 7 - Exemplos de comensalidade nos filmes da década de 90. De cima para baixo, respectivamente: Tomates Verdes Fritos

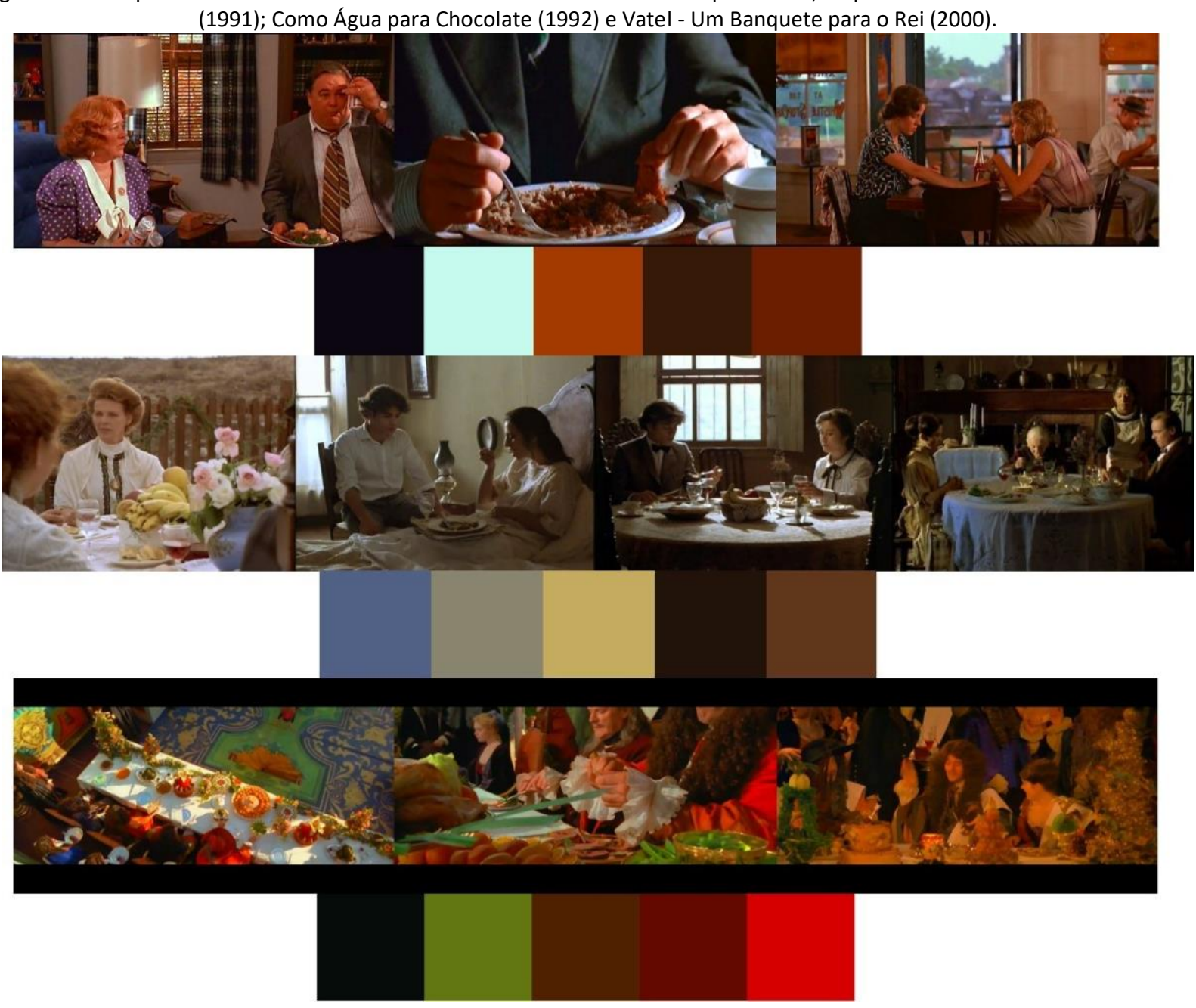

Fonte: elaborado pelo autor.

Figura 8 - Exemplos de cenas sobre comensalidade: Mais Estranho que Fiç̧ão (2006) acima e Sem Reservas (2007) abaixo.
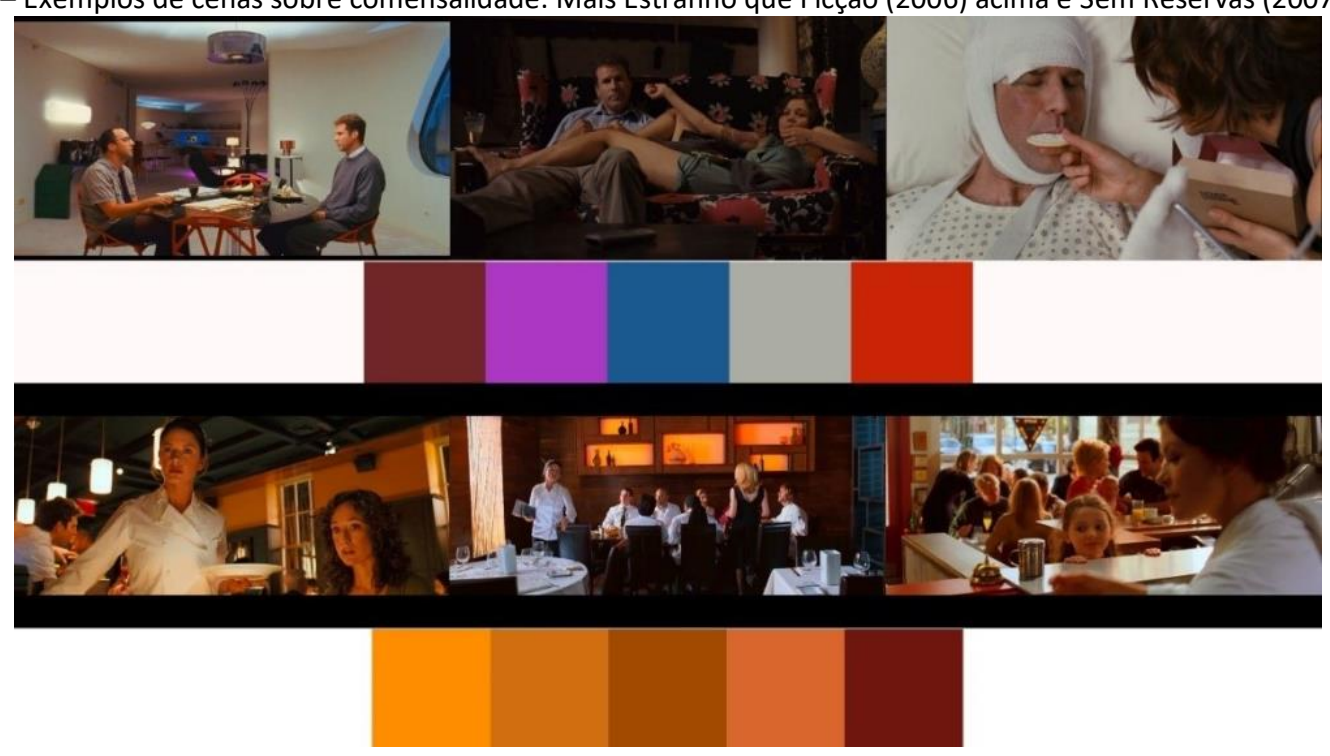

Fonte: elaborado pelo autor 


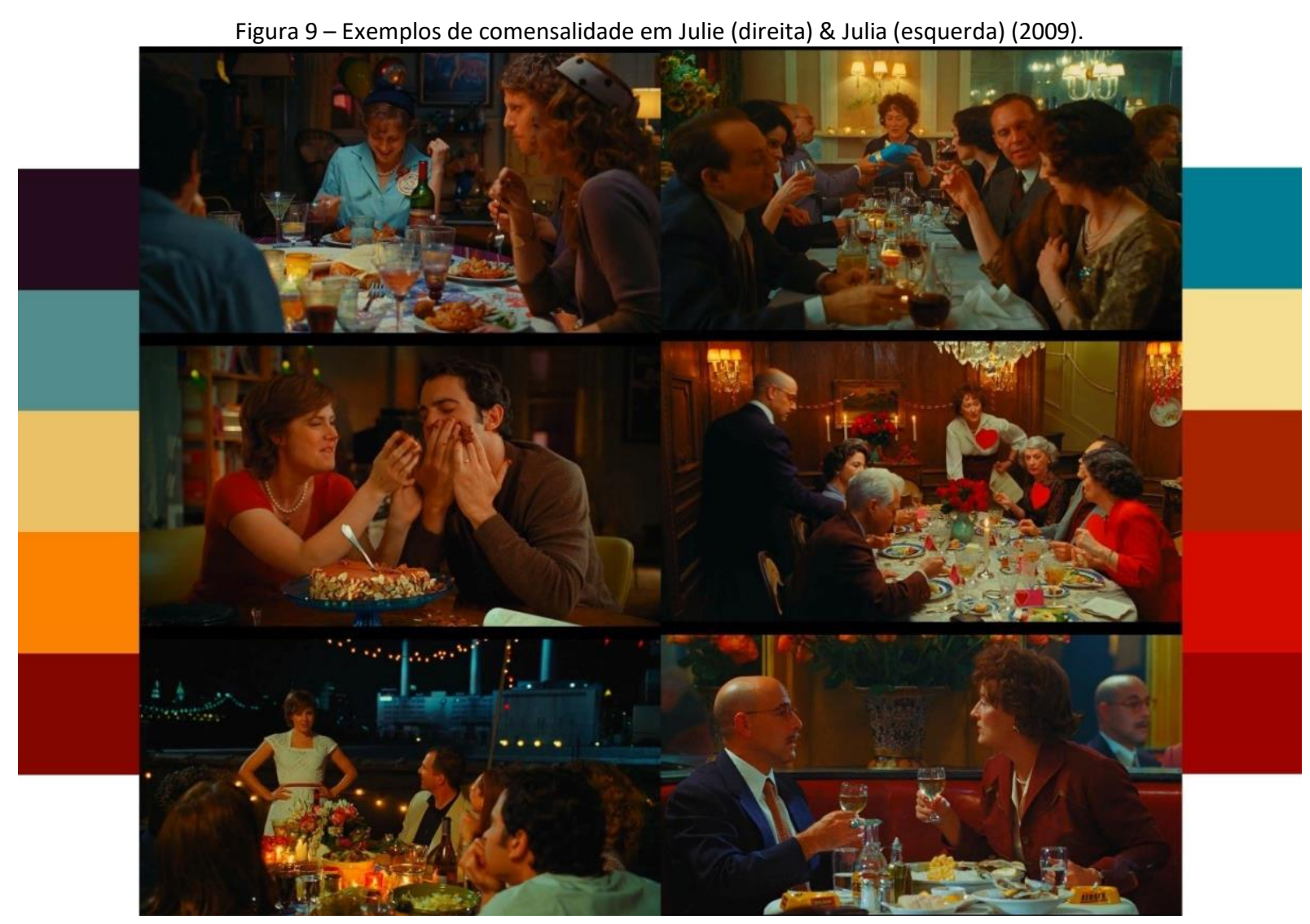

\section{CONCLUSÕES}

No primeiro aspecto analisado, a cozinha, é possível notar um clareamento na paleta cromática em cenas que retratam o aspecto analisado. Os três filmes da década de 90 escolhidos retratam a cozinha como um ambiente escuro (preto, marrom, cinza), com cores mescladas com o preto que empobrecem a imagem (figura 2) (PEDROSA, 2013). Já os filmes da primeira década do século XXI (figura 3) contêm vermelho, laranja, verde, azul e branco. Concluindo-se que houve uma nova forma de se abordar e retratar a cozinha em relação à paleta cromática.

No segundo aspecto analisado, a mesma característica foi observada. Ao comparar as figuras 4 e 5 (que retratam o cozinhar dos filmes da década de 90) com a figura 6 (referente aos filmes restantes) observa-se que o cozinhar ganhou mais tempo de tela e a paleta cromática sofreu um clareamento. É possível notar a presença do amarelo, branco e azul.

A comensalidade dos filmes da década de 90 também é retratada com uma paleta cromática escura, entretanto sempre há presente alguma cor mais alegre (figura 8), mantida e aprimorada nos filmes mais novos (figuras 8 e 9). A figura 7, da película Vatel, retratam a comensalidade com cores muito mais vibrantes que as usadas na cozinha (figura 5), destacando o verde, amarelo, vermelho, laranja e branco e dando à imagem uma valorização e um requinte. É interessante observar como a 
cozinha e o ato de cozinhar nesses filmes é retratado com uma fotografia mais escura e a comensalidade possui a quantidade de cores observada.

É pertinente atentar o período em que essa troca ocorre. Depois da virada do milênio, a gastronomia alcançou destaque em diversas áreas. De 2001 a 2010 foram lançados 58 filmes sobre o tema contra 54 lançados da década de 30 até os anos 2000 (YASOSHIMA, 2012).

O cenário nesse período para a gastronomia foi positivo, sua representação crescia em revistas, televisão e no cinema em grandes quantidades, como observado. Com o boom da gastronomia, a cozinha e o cozinhar passaram a ser representados de uma maneira mais atrativa no cinema, considerando a paleta cromática, e consequentemente ganhando seu público.

Quase todos os filmes, mesmo as comédias, tratavam de certos problemas das relações humanas, e a maneira como uma glamorosa estrela do cinema resolve seus problemas. O comportamento desses astros do cinema vai influir no pensamento do povo e como esses resolverão seus próprios problemas. Os filmes têm um realismo de superfície que tende a camuflar a fantasia e fazê-la parecer verdadeira. "todo lazer é educação em certo sentido, as vezes mais efetivamente do que as escolas, devido ao apelo as emoções mais do que o intelecto, os filmes são uma escola de conduta, pois trata se de um assunto que interessa a todos (CICCO, 1994, apud BECKER, 2008, p. 21).

Becker (2008) ainda descreve a facilidade com que a cultura norte-americana tem facilidade em atingir o público jovem, fazendo com que esses queiram ser como os atores dos filmes, alterando seus comportamentos, além de lançar na moda frases, gestos e trajes dos astros do cinema.

Agora que a influência causada pelo cinema no espectador foi analisada, deve-se associar como a cor o influencia. Battistella, Colombo e Abreu (2010, p. 9) estudaram a cor de embalagens como fator influenciador no momento da compra de um produto e concluíram:

Sem dúvidas, a cor da embalagem é um de seus elementos principais, compondo com a forma e o material todo em si. É ainda extremamente relevante a participação da embalagem e por extensão, da cor, no complexo e intrigado processo mercadológico. Em outras palavras, a cor da embalagem age diretamente no processo de venda dos produtos, atraindo, cativando e convencendo o consumidor.

Então a cor da embalagem age diretamente na venda do produto, atrai, cativa e o convence. Quando esse produto é um filme, pode-se concluir que a paleta cromática das cenas tem influência direta sobre o espectador, positiva ou negativamente.

De acordo com o pequeno manual de análise sensorial do Slow Food Brasil (BARZANO; FOSSI, 2009), a visão é o sistema sensorial responsável por $80 \%$ das informações que chegam ao cérebro. Não apenas a cor, mas a forma e o aspecto são informações úteis na escolha de um alimento. Espera-se que um tomate verde seja ácido, que um doce marrom tenha gosto de chocolate e 
desconfia-se de alimentos que não possuem cores familiares, por isso a indústria alimentar utilizase de aditivos para modificar as cores de produtos. Essa modificação remonta aos tempos dos romanos, que usavam o açafrão para colorir suas comidas com um amarelo, tranquilo e harmônico.

Durante a análise diacrônica, a qual organizou os filmes em uma linha de tempo destacando a paleta cromática da cozinha, do cozinhar e da comensalidade, elementos presentes em todos os filmes analisados, foi possível identificar uma mudança em determinadas representações da gastronomia no cinema.

As cores vivas presentes no ambiente causam uma automática simpatia, são cores que se comunicam com o espectador de uma forma positiva: o amarelo chama a atenção e causa sensação de aproximação; o azul é percebido como frio e purificador, além de profundo e misterioso; o laranja é quente, extrovertido e chamativo; o verde é associado à esperança, primavera, bosques e a serenidade. Valorizando a imagem da cozinha e tornando agradável o ambiente (OLIVEIRA, 2016; SCHWENDLER, 2015; FREITAS, 2007; FARINA; BASTOS; PEREZ, 2011).

Essas cores trazem então positividade ao espectador, mas nos três primeiros filmes cronologicamente analisados (Tomates Verdes Fritos, Como Água para Chocolate e Vatel - Um Banquete para o Rei), a cozinha e o cozinhar estudados não carregam essas cores, pelo contrário, são repletas de cores escuras, com baixa iluminação, concluindo-se que o objetivo não era representar esses dois aspectos de forma positiva. Já as cenas que retratam a comensalidade, todos os filmes analisados possuíam a paleta cromática com cores vivas e alegres, como se apenas o comer fosse algo agradável e o cozinhar depressivo.

A paleta cromática, que retrata a gastronomia nos filmes mais novos (pós 2001), é notavelmente mais chamativa que os antigos ao filtrarmos as cenas dentro da cozinha e de personagens cozinhando que os filmes lançados nos anos 90.

Nesta pesquisa foi concluído que, no recorte predeterminado, os filmes dos anos 90 representavam a imagem da cozinha e do cozinhar como algo sofrido, árduo, que não merecia tanto destaque como as cenas de comensalidade dos mesmos filmes. O comer sempre foi prazeroso, desejado e colorido.

Já nos filmes de 2001-2010, no período de crescimento da gastronomia contemporânea, as cores chamativas não ficaram restritas apenas à comensalidade, mas foram utilizadas na cozinha e o ato de cozinhar. A gastronomia ganhou um tipo de associação subjetiva positiva, cozinhar é divertido, é terapia, é um hobbie, é uma forma de vida e é mais colorido. 


\section{REFERÊNCIAS}

ABREU, T.; ANDRADE, A. O Uso da Cor no Cinema de Animação de Tim Burton. Anagrama, São Paulo v. 10, n. 1, p. 115, 4 jan. 2016. Disponível em: http://www.revistas.usp.br/anagrama/article/view/108967. Acesso em: 23 abr. 2019.

BARRETO, R. L. P. Passaporte para o sabor: tecnologias para a elaboração de cardápios. 4. ed. São Paulo: Senac, 1999.

BARZANO, C.; FOSSI, M. Pequeno manual de educação sensorial. São Paulo: Slow Food, 2009.

BATTISTELLA, N.; COLOMBO, J. R.; ABREU, K. C. K. A Importância da cor nas embalagens como fator influenciador no momento da compra. Biblioteca Online de Ciências da Comunicação, [20??]. Disponível em:

http://www.bocc.ubi.pt/pag/bocc-kraemer-embalagens.pdf. Acesso em: 23 abr. 2019.

BECKER, C. K. História e cinema: a influência cultural norte-americana no Brasil através do cinema $\mathrm{X}$ ensino de História. 2008. 40f. Trabalho de Conclusão de Curso (Pós-Graduação em História, Ensino e Linguagens) - Universidade do Extremo Sul Catarinense, Criciúma, 2008.

BRAGA, N. R.; KUNRATH, K.; MEDEIROS, L. Metodologia projetual e aplicação cromática. Anais... Congresso Brasileiro de Pesquisa em Desenvolvimento em Design, 8. São Paulo, p. 3084-3088, out. 2008.

BRILLAT-SAVARIN, Jean-Anthelme. A fisiologia do gosto. São Paulo: Cia. das Letras, 1995.

CHENILLE, V. Le plaisir gastronomique au cinema. Paris: Jean-Paul Rocher, Éditeur, 2004.

FARINA, M.; PEREZ, C.; BASTOS, D. Psicodinâmica das cores em comunicação: 6. Ed. São Paulo: Edgard Blücher, 2011.

FREITAS, A. K. M. Psicodinâmica das cores em comunicação. 2007. Disponível em:

https://www.iar.unicamp.br/lab/luz/ld/Cor/psicodinamica_das_cores_em_comunicacao.pdf. Acesso em: 23 abr. 2019.

GUEDES, W. A. Brasil Canibal: em busca de uma história do conceito de antropofagia no filme Macunaíma. Anais... Simpósio Nacional de História, 25., Fortaleza, 2009. Disponível em:

http://www.snh2011.anpuh.org/resources/anais/anpuhnacional/S.25/ANPUH.S25.0039.pdf. Acesso em: 23 abr. 2019.

GUIMARÃES, L. A cor como informação: a construção biofísica, linguística e cultural da simbologia das cores. 3. ed. São Paulo: Annablume, 2001.

HÉRCULES, L. C. A cor na análise fílmica: um olhar sobre o moderno cinema francês. Revista Comunicación, São Paulo, v. 1, n. 10, p.1309-1322, 2012.

KELLNER, D. Gênero e Hollywood. In: HILL, J.; GIBSON, P. C. American Cinema and Hollywood: critical approaches. Oxford: Oxford University Press, 2000.

LUDERER, C. A. F. O papel dos chefs-celebridades na construção do espetáculo da alimentação: análise discursiva das revistas de gastronomia de luxo. 2013. 458f. Tese (Doutorado em Comunicação) - Pontifícia Universidade Católica de São Paulo, 2013.

MONTORO, T. Cinema é alimento para o corpo e a alma. Comunicação e Informação, v. 10, n. 1, p. 8-15, jan./jun. 2007. Disponível em: https://www.revistas.ufg.br/ci/article/view/10290/7163. Acesso em: 23 abr. 2019.

NEVES, J. S. O. Entre preto e branco: para uma estética monocromática do cinema depois do technicolor. $347 f .2015$. Tese (Doutorado em Ciência e Tecnologia das Artes) - Universidade Católica Portuguesa, Escola das Artes, 2015.

NOGUEIRA, L. Cinema e jornalismo: o melodrama e a tragédia moderna. Significação: Revista de Cultura Audiovisual, Goiânia, v. 35, n. 30, 2008. Disponível em: http://www.revistas.usp.br/significacao/article/view/65677. Acesso em: 23 abr. 2019.

OLIVEIRA, H. C. Desenvolvimento de guia cromático com foco no cinema do terror. 2016. 217f. Trabalho de Conclusão de Curso (Bacharelado em Design) - Universidade Federal de Santa Catarina, Florianópolis, 2016. 
PEDROSA, I. Da cor à cor inexistente. 2. ed. Rio de Janeiro: Senac Nacional, 2013.

PEDROSA, I. O universo da cor. Rio de Janeiro: Senac Nacional, 2008.

PETER, Cris. O Uso das Cores. Rio de Janeiro: Marsupial, 2014.

RAMOS, F. P. A Socine e os Estudos de Cinema na Universidade Brasileira. Global Media Journal Brazilian Edition. v.1, n. 1, p. 1-7, 2009. Disponível em: http://periodicos.ufes.br/gmj/article/view/541. Acesso em: 23 abr. 2019.

RICCI, C. S. Pesquisa como ensino. Belo Horizonte: Instituto Cultiva, 2003.

SCHWENDLER, B. L. As Cores e o Cinema: uma análise do filme Moonrise Kingdom (2012), de Wes Wanderson. 2015. Trabalho de Conclusão de Curso (Bacharel em Comunicação Social com habilitação em Publicidade e Propaganda) Faculdade de Biblioteconomia e Comunicação, Universidade Federal do Rio Grande do Sul, Porto Alegre, 2015.

SILVA, C. C. A teoria das cores de Newton: um estudo crítico do Livro I do Opticks. 1996. 132f. Dissertação (Mestrado em Física) - Universidade Estadual de Campinas, Instituto de Fisica "Gleb Wataghin.", Campinas, SP. Disponível em: http://www.repositorio.unicamp.br/handle/REPOSIP/277093. Acesso em: 21 jul. 2018.

SILVEIRA, L. M. Introdução à teoria da cor. 2. ed. Curitiba: Ed. UTFPR, 2015.

WITTER, G. P.; RAMOS, O. A. Influência das cores na motivação para leitura das obras de literatura infantil. Psicol. Esc. Educ., Campinas, v. 12, n. 1, p. 37-50, June 2008. Disponível em:

http://www.scielo.br/scielo.php?script=sci_arttext\&pid=S1413-85572008000100004\&lng=en\&nrm=iso. Acesso em: 03 nov. 2018.

YASOSHIMA, J. R. Gastronomia na tela: as representações da comida no cinema. Revista Rosa dos Ventos, Caxias do Sul, v. 4, n. 3, 2012, p. 300-316. Disponível:

http://www.ucs.br/etc/revistas/index.php/rosadosventos/article/view/1759. Acesso em: 23 abr. 2019. 